\title{
University of Tasmania
}

\author{
Danielle Wood
}

\section{Strategic, stylistic and notional intertextuality: Fairy tales in contemporary Australian fiction}

\begin{abstract}
:
While Canadian scholar Lisa M Fiander argues that fairy tales are 'everywhere' in Australian fiction, this paper questions that assertion. It considers what it means for a fairy tale to be 'in' a work of contemporary fiction, and posits a classificatory system based on the vocabulary of contemporary music scholarship where a distinction is made between intertextuality that is stylistic and that which is strategic. Stylistic intertextuality is the adoption of features of a style or genre without reference to specific examples, while strategic intertexuality references specific prior works.
\end{abstract}

Two distinct approaches to strategic fairy-tale revision have emerged in Australian writing in recent decades. One approach, exemplified in works by writers including Kate Forsyth, Margo Lanagan and Juliet Marillier, leans towards the retelling of European fairy tales. Examples include Forsyth's The Beast's garden ('Beauty and the Beast'), Lanagan's Tender morsels ('Snow White and Rose Red') and Marillier's short story 'By bone-light' ('Vasilisa the Beautiful'). The other, more fractured, approach is exemplified in works by writers including Carmel Bird and Murray Bail, which do not retell fairy tales but instead echo them and allude to them.

This paper proposes that recent Australian works that retell fairy tales are less likely to be set in a recognisably Australian context than are works which take a more fractured approach to fairy tale. It also explores the notion that, presently, transporting European fairy tales, whole, into an Australian setting, seems to be a troubling proposition for writers in a post-colonial settler society that is highly sensitised to, but still largely in denial about, its colonial past.

Biographical note:

Dr Danielle Wood completed her PhD at Edith Cowan University in Western Australia. Her thesis included the novel The alphabet of light and dark, which won The Australian/Vogel Literary Award in 2002 and the Dobbie Literary Award in 2004. Her works include Rosie Little's cautionary tales for girls, Mothers Grimm and Housewife superstar: The very best of Marjorie Bligh. Dr Wood has collaborated with fellow Tasmanian writer Heather Rose, under the pen name 'Angelica Banks', to produce a trilogy of adventure stories featuring a young writer, Tuesday McGillycuddy. Finding 
serendipity, A week without Tuesday and Blueberry pancakes forever have been published in Australia, Germany and the USA.

Keywords:

Creative writing - Fairy tales - Australian fiction 
'Fairy tales are everywhere in Australian fiction', writes Canadian scholar Lisa M. Fiander in a 2003 article in the Journal of the Association for the Study of Australian Literature (2003: 157). She is not being literal, of course; I take her to mean that fairy tales are a common feature in Australian fiction, especially in the last two decades of the twentieth century, the period in which she focuses her reading. But - even if we resolutely leave on the shelf that can of worms containing the debate over the meaning of the term fairy tale (and we will do just that) - there is much in Fiander's statement to consider. Is she right? Are fairy tales prevalent in Australian fiction? How we might evaluate this will depend on how the term Australian fiction is defined. Does it mean fiction by Australian writers, or fiction set in Australia, or fiction that is both by Australian writers and set in Australia, or something else? Also, since fairy tales can provide, for works of contemporary fiction, everything from the lightest touch of influence to their entire structural core, we might also ask precisely what it means for a fairy tale to be considered to be 'in' a work of fiction. In this essay, and writing from the position of one who is both a reader of fairy tale-inflected fictions and a writer of the same, I put forward (yet another) possible vocabulary for discussing the different ways in which fairy tales appear in contemporary fictions. Following this, I offer the observation that the use of fairy tales in contemporary fiction by Australian writers appears to be more constrained when those fictions are in set in a recognisably Australian context than when they are set in other geographical locations, or, indeed, in the 'timeless, spaceless, quasimythic sphere' (Thomas 1986: 126), that is traditionally conjured with the words 'once upon a time'.

There is no shortage of ready-made classificatory systems for describing how fairy tales appear as intertexts in contemporary texts. For my purposes, I wanted a classificatory system that had more categories than Zipes's binary duplication/revision model - in which contemporary fairy-tale texts either '[reinforce] the deeply entrenched modes of thinking, conceiving, believing that provide our lives with structure' (1994: 8) or 'create something new that incorporates the critical and creative thinking of the producer and corresponds to changed demands and tastes of audiences' (1994: 9) - or De Caro and Jordan's binary, which proposes that some contemporary works are scaffolded by the 'formal or stylistic framework' of folkloric texts, so that folklore becomes the "“exoskeleton"' of the new work, while other contemporary works use folklore as an “"endoskeleton” of plot, reference, or meaning' (2004: 7). However, I did not require so many categories as the eight that Smith offers in The postmodern fairytale. Nor did I require the seven categories, elucidated by Joosen, wherein contemporary fairy-tale re-tellings disrupt the 'horizon of expectation' (Joosen 2011: 12-13) that readers are bound by when they encounter a traditional fairy tale.

For my purposes, a useful place to look for a suitable vocabulary to describe the degrees and purposes of fairy tale incorporation within contemporary fiction is the world of popular music, where older songs are referenced, recycled and repurposed through new ones. In this analogy, fairy tales are, of course, the old and well-known songs whose success, longevity and familiarity make them appealing hooks for contemporary writers to employ when constructing new fictions. Warner has noted that fairy tales, rather than existing in fixed form, are more like 'tune[s] that can migrate from a symphony to a penny whistle' (2014: n.p.). As in music, literature provides a range of models for the 
ways in which artists might choose to respond to, and incorporate elements of, those prior texts that have inspired or influenced them.

In 1985, music theorist Robert Hatten announced that he was borrowing from literary studies the term intertexuality. In an article that acknowledges but ultimately rejects what Hatten calls a radical understanding of the term (in which intertextuality is seen as a fundamental condition of all texts), he propose the usefulness, to music studies, of the term in its more commonly understood and limited definition. He argues that music scholars might helpfully 'distinguish the contexts of style and strategy as regulators of relevant intertextual relationships’ (1985: 70, emphasis added). Following Hatten, Mark Spicer elucidates as follows:

[s]tylistic intertextuality occurs when a composer adopts distinctive features of a preexisting style without reference to any specific work in that style [while s]trategic intertextuality is more pointed, occurring only when a composer makes deliberate reference to a particular earlier work or works, and this can involve a variety of techniques such as quotation, structural modeling, variation or paraphrase. (2009: 353)

As an example of stylistic intertextuality, Spicer cites the Beatles' song 'Eleanor Rigby' and its appropriation of high-Baroque devices in its memorable strings accompaniment. Here, Paul McCartney, the songwriter, does not reference a specific prior composition, but instead an entire musical style. By borrowing attributes of this style, he effectively layers its textures into his song; the listener, whether consciously, subconsciously or semi-consciously, then imports into a listening experience whichever associations they attach to the source style. Analogously, a fiction writer might choose to reference fairy tale in a work of fiction, not by referencing a specific tale, but by gesturing to the entire genre through use of particular stylistic devices. These could include such things as patterns of three (three daughters, three sons, three wishes, three challenges), starkly opposed character types (good sister/bad sister, clever son/stupid son, weak husband/nagging wife), the setting of impossible quests, or the appearance of magical helpers. Through stylistic intertextuality, a fiction writer can leverage the entire repertoire of associations that a reader attaches to fairy tale in general, and these associations are often powerful. An example of stylistic intertextuality in Australian fairy-tale reinvention comes in Murray Bail's Miles Franklin award-winning novel Eucalyptus, named for the most iconic of Australian trees, and set four hours west of Sydney ('in a Japanese car' (1998: 2)). Page one begins with a riff on Eucalyptus desertorum, but two pages later Bail capitulates to another sort of beginning:

Once upon a time there was a man-what's wrong with that? Not the most original way to begin, but certainly tried and proven over time, which suggests something of value, some deep impulse beginning to be answered ... (1998: 3).

And with this, Bail signals his project: to write a new fairy tale, about the quest that ensues when a man offers his daughter Ellen's hand in marriage to the first prospective suitor who can correctly name every species of eucalypt in his 'outdoor museum of trees' (1998: 45).

In popular music, strategic intertextuality might be seen to encompass two popular and commonly understood models of adaptation, in which new songs make pointed reference to older ones. One is performing or recording a cover version of an earlier 
work by another artist, and the other is sampling: including a segment of an older song within the fabric of a new one. The history of the song 'Tainted love' provides a neat illustration of both strategies. The song was written by Ed Cobb and recorded in 1964 by Gloria Jones, then famously covered - effectively copied, but also significantly modified and updated - by Soft Cell in 1981. Then, in 2006, Rihanna released the song 'SOS', which features the prominent use of a two-bar loop sampled from Soft Cell's 'Tainted love' (Rihanna's song's writing credit is shared between Jonathan Rotem, E. Kidd Bogart and the original 'Tainted love' writer, Ed Cobb). As early as 1956 John Cage predicted that 'in the future, records will be made from records' (quoted in Duffel 2005, 202), and the contemporary abundance of cover versions and songs made through sampling technology realises his prediction in two ways, one even more literal than the other. While cover versions are effectively made out of such features of an existing song as its lyrics and notation (though both may be varied), songs made from samples treat an existing song's actual recorded sound as raw material. To apply the analogy, a fiction writer might retell a fairy tale (create a cover version), by borrowing its overall narrative structure. Or, they might alternatively extract well known and resonant aspects of a fairy tale and build these into the fabric of a new story (sampling). Riffs are sampled into new songs because they are proven. Fragments of fairy tales, likewise, are embedded in new tales because they work on readers through association, familiarity and sheer addictive catchiness.

The effect or meaning that is produced by the re-presentation of an existing text, musical or literary, will depend, of course, on the intention of the re-presenter. Musical cover versions might be 'straight', as in the performances by tribute bands, where the motive of the contemporary artist is to replicate the work of a forerunner as exactly as possible (Butler 2010: n.p.). This is often an act of homage; the chief goal is to give contemporary audiences the pleasure of experiencing creative artefacts from the past, without significant variation (as in Zipes's duplication model). In the world of fairytale re-presentation, examples of such 'straight' cover versions would include the tales as they appear in certain picture books, where the primary focus of republication is the creation of visually appealing and commercially successful editions. Indeed, the text as it appears in such books may be very close to translations of tales as set down by the Grimms, Perrault or other collector/writers.

But not all cover versions are 'straight'. Butler writes:

A second form of cover stays close to the song structure of the original, but recasts it, changing elements to reflect the covering band's usual style and sound of performance. The third type of covers are based on the original but radically altered so that the cover appears as a critique or interpretation of the original version. (2010: n.p.)

This second form of cover version might be exemplified by Philip Pullman's 2012 collection Grimm Tales for Young and Old, released to coincide with the 200th anniversary of the publication of the first edition of the Grimms' Kinder-und Hausmärchen. The structures of the fifty included tales are not altered in Pullman's retellings, but details are added or subtracted, and the stripped-back narrative voice is distinctly contemporary. As Guardian reviewer Sara Maitland commented: although Pullman notes in his introduction his 'desire to keep himself back, to create a voice as 
"clear as water" and focus solely on the story rather than a personal interpretation' (2012: n.p.), his own voice (his 'usual style and sound of performance' (Butler 2010: n.p.) rings out on every page. As for the third type of cover version, surely Angela Carter's seminal The bloody chamber collection - in which a version of Bluebeard's wife is rescued by her pistol-toting, firebrand mother, and a version of Little Red Cap knowingly and willingly enters into a sexual relationship with the wolf - provides the internationally recognised exemplar of fairy-tale adaptation as critique.

When fairy tales are reinvented as cover versions, the relationship between the old and the new is usually clearly signalled in the title of the work, and/or in the para-textual material associated with its publication, and/or in the marketing of the new title. Notable examples from the cover version school of fairy-tale reinvention here in Australia include Kate Forsyth's Bitter greens (2012), a multi-stranded elaboration on 'Rapunzel', and her The Beast's garden (2015), which is described by its publisher as 'a retelling of the Grimms' Beauty and the Beast, set in Nazi Germany'; James Bradley's Beauty's Sister (2012), a retelling of 'Rapunzel'; Margo Lanagan's Tender morsels (2008), a dark and disturbing retelling of 'Snow White and Rose Red', and also her Sea hearts (2012), extrapolated from selkie myths of Celtic origin; and Juliet Marillier's 'By bone-light' (2013), a retelling of the Slavic tale 'Vasilissa the wise' set in a contemporary apartment block with a basement-dwelling Baba Yaga. When approaching any of these texts, it's likely that the reader a) already knows that the contemporary text is based on a well-known source tale, b) has some degree of knowledge - whether detailed or scant - about the content of the source tale, and c) has some expectations about how the new story will intersect with the structures of the old. This is less true in the case of contemporary texts that use strategic intertextuality as sampling. Here, readers are often left to work out for themselves which stories are being referenced, and what the significance of the references might be. De Caro and Jordan observe that folklore, within contemporary texts, has a 'referential function in calling attention to meaning' (2004: 8, emphasis in original).

The Australian writer who has done more with fairy tale than any other is Carmel Bird. Yet, of her full-length works, only Cape Grimm (2004) and Red shoes (1998) signal a fairy-tale debt in their titles. Bird is the consummate sampler; many of her novels and short stories, as well as a recent work of non-fiction/memoir, Fair game: a Tasmanian memoir (2015), are richly interwoven with references to the fairy tale-tradition. She traces her long-standing fascination with fairy tale to her upbringing in Tasmania, a location, she says: 'that pops up in literature when a writer seeks a far off, inconsequential, mythical or gruesome place to insert into the prose' (2015: 10), and a place that she, as a girl, experienced as 'strange and haunted' (2004, 11). Those three of her novels - The white garden (1995), Red shoes (1998) and Cape Grimm (2004) that comprise a trilogy on the relationship between charisma and evil, each incorporate motifs from, and references to, specific well-known fairy tales. In The white garden, Ambrose Goddard's pioneering Deep Sleep Therapy treatments enable him to rape his female patients in the 'Sleeping Beauty' ward. Red shoes, a novel that shares a title with a literary fairy tale by Hans Christian Andersen, features a group of girls who are drugged and brainwashed by the charismatic cult leader Petra Penfold-Knight, and who remind the reader of the bewitched heroines of 'The Twelve Dancing Princesses'. Cape 
Grimm, set in the northern Tasmanian location of Cape Grim (though with an extra ' $m$ ' to underscore the narrative's relationship to fairy tale), is a complex novel of intersecting storylines in which the sad history of the Tasmanian Aborigines provides a historical counterpoint for a late twentieth century mass killing. The victims are members of a religious community: the perpetrator is their leader. Cape Grimm concludes with an appendix that glosses the various myths and fairy tales that are sampled throughout the text: the story of Alcyone and Ceyx, 'Hans my hedgehog', 'The juniper tree', and 'Rapunzel'. Bird works by planting images from these tales within her fictions and leaving them there, like depth charges, to quietly explode their accumulated meanings in the reader's psyche.

Both my collections of fairy-tale influenced fictions, Rosie Little's cautionary tales for girls (2006) and Mothers Grimm (2014), borrow copiously from specific tales, but do not attempt to retell them in their entirety. I have heard from some readers of my collection, Mothers Grimm, that its four stories didn't meet the expectations they had set up, based on their reading of the book's title and cover art. Instead of the re-told but twisted tales they expected, they found only hints and echoes and glimpses of the source texts. Some readers have also commented that Mothers Grimm let them down because the stories it contains are bleak. Nan McNab, in her introduction to Tales from the tower volume two: The wicked wood, observes that while:

[f]airytales can be many things...they are almost never sad. Sadness grows out of incompleteness, a sense of "if only", a yearning for resolution and in fairytales there is a remorseless sense of completeness, of everything being in its proper place. (in Carmody \& McNab 2011b: 5)

For me, part of the attraction of the sampling school of strategic intertextuality is that frees the writer from the necessity (the tyranny?) of completion, and allows the most arresting, irresistible parts of a fairy tale to sing out from within works that might, indeed, be written in a minor key.

Fairy tales, then, are 'in' Australian fiction as stylistic intertexts, as structural strategic intertexts (as in the cover version school of fairy-tale reinvention), or as textural strategic intertexts (as in the sampling school). But there's another way that fairy tale is used in contemporary Australian fiction, and that is through the deployment of glancing references to fairy-tale ideas, or perhaps only the inclusion of the word/s fairytale/fairy tale. If we were looking for a term for this, we might call it notional intertextuality. An example of it occurs in the short biography for Victor Kelleher that appears in the closing pages of Tales from the tower volume two: The wicked wood. Since the six biographies in this volume are written in distinctly different styles, I think it probable that Kelleher supplied his own third-person biography. It details how he was raised in the East End of London by 'semi-literate grandparents' and attended a series of 'appalling back-street schools' (in Carmody \& McNab, 2011: n.p.). But, at the age of fifteen, he 'had just enough sense to escape to Central Africa, where he felt that he'd been reborn into a fairytale [one word, in this instance] world of sunlight and plenty' (in Carmody \& McNab, 2011: n.p.). Here, the single word fairytale imports into Kelleher's personal narrative notions of complete otherness, other-worldliness, magic and transformation. 
When Lisa M Fiander says ‘[f]airy tales are everywhere in Australian fiction' (2003: 157), with reference to the fictions of the late twentieth century, is it possible that what she might be seeing in high frequency is notional intertextuality, which invokes the idea of fairy tale generally? She cites the moment in Peter Carey's True history of the Kelly Gang in which Ned Kelly refers to the Great Dividing Range as 'a fairy story landscape' (quoted in Fiander 2003: 158), and the moment in Carey's Oscar and Lucinda in which Oscar sees a view of a Bellingen estuary as 'an illustration to a fairy tale' (quoted in Fiander 2003: 163), and also numerous other examples from contemporary Australian texts in which Australian geography is seen through the eyes of non-indigenous characters as other, or indeed other-worldly, just as Kelleher reports his young self perceived Africa as a fairytale world. Fiander persuasively builds the case that the frequent (notionally intertexual) references to the idea of fairy tale in Australian fiction are usually linked to a feeling of being out of place in a landscape, to a sense of unbelonging. She says it is 'Australia's history as a settler colony, geographically far removed from the European origins of most of its early arrivals, which likely accounts more than anything else' (2003: 160) for this trend.

Since the publication of Fiander's article, much has changed in the fairy-tale space in Australia. The establishment of two groups dedicated to the exploration of the fairytale tradition in Australian letters - the Australian Fairy Tale Society (AFTS) and the Monash Fairy Tale Salon (MFTS) - provides an indicator not only of increased activity in the critical sphere, but also in the creative sphere. Fairy-tale scholarship, internationally, is a discipline unusually well-attuned to the productive links between creative and critical endeavour; Vanessa Joosen argues that ' $[\mathrm{t}]$ he hybridity of the fairytale retelling exists not only in its obvious connection with the traditional fairy tale but also in its overlaps with fairy-tale criticism' (2011: 2). Events hosted in Australia by the AFTS and MFTS have openly embraced a strong creative presence, and it is also the case that, in recent years, fairy tale has provided the focus for some significant publishing enterprises. In a project instigated by Carmel Bird, the Australian literary magazine Griffith Review dedicated a 2013 edition, titled Once upon a time in Oz, to the exploration of the place of fairy tale in Australian literature, current affairs and popular culture. Meanwhile, Isobel Carmody and Nan McNab teamed up to edit Tales from the tower volume one: The wilful eye (2011a) and Tales from the tower volume two: The wicked wood (2011b). These three publications have provided both an invitation and a venue for Australian writers to experiment with fairy tale. And yet, despite all this activity, it seems to me that the use of fairy tale in Australian fictions with Australian settings remains curiously constrained, with fairy tale being incorporated most often in the manner of notional intertextuality or the less explicit forms of strategic intertextuality.

In the notable cover versions listed above, all of them by Australian writers, Australia as a setting is hard to locate. Forsyth sets both Bitter greens and The Beast's garden in Europe, while Bradley's Beauty's sister is set in a quasi-mythic fairy-tale everywhere/nowhere. Lanagan's Tender morsels is set in the quasi-mythic sphere, while her Sea hearts invents the fictional, fantastical setting of Rollrock Island and its immediate surrounds. Marillier's 'By bone-light' might be set in contemporary urban Australia: one floor of the apartment block in which the action takes place is called 
'Eucalyptus'. But the tale could just as easily be understood to be located in any contemporary Western urban location, since every other floor of the apartment block is named for a European species of tree. Of the twelve stories in the two Tales from the tower volumes - each one of them clearly connected to a well-known fairy tale, for such was the brief for contributors - only Cate Kennedy's story 'Seventy two Derwents' (which retells 'The wolf and the seven kids'), Nan McNab's 'Glutted' (which retells the Czech fairy tale 'Otesaned'), and Maureen McCarthy's 'The ugly sister' (a 'Cinderella' retelling), are very obviously set in Australia. A further two stories are possibly set in Australia, while the remainder are set in a fairy-tale or fantasy location, an international locale, or else in a geographically uncertain, semi-realist 'now'. Australia features much more prominently in the settings of the fictions that appear in Once upon a time in $\mathrm{Oz}$, but in this publication - for which the brief provided to contributors was more open than was the case for the two Tales from the tower volumes - there are fewer explicit connections between the new fictions and specific fairy-tale source texts. The clearest connections come in Ali Alizadeh's story 'Snow White and the child soldier' and both Cate Kennedy's 'A glimpse of paradise' and Marion Halligan's 'A castle in Toorak': two stories that feature dangerous Bluebeards at home in Australian suburbia. The other fictions have more fragmented or elusive connections to specific source tales.

There seems to me to be a conundrum in fairy-tale intertextuality in Australian fiction. While on the one hand there seems to be a close relationship between fairy-tale intertextuality and Australian place (Bird/Tasmania, Fiander/references to Australian geographical locations as fairy-tale settings), and a passion for fairy-tale retellings among Australian writers (says Kate Forsyth, 'I find it very interesting that so many Australian writers are drawn to retelling fairy tales' (2016: n.p.)), there also seems to be a curious restraint around locating fairy tales, whole, in Australian settings. To put it another way, Australian place has simultaneously fulfilled 'the role of a fairy realm' (Do Rozario 2011: 14), and proved itself resistant to the fairy tale. As Bullen and Sawer argue, 'the fairy tales of the northern hemisphere did not easily take root in the antipodes' (2016: 233).

Is it possible that when Australian writers engage in strategic intertextuality of the cover version kind, that they are less likely to set their new works in an Australian context? Or that when Australian writers want to put fairy tales into new fictions that do have a recognisably Australian setting, they are more likely to employ strategic intertextuality of the sample kind, fracturing their source stories and borrowing only hints and echoes of them, rather than importing an entire narrative frame? I do not mean to suggest, at all, that Australian writers ought to do more in the way of producing noticeably Australian cover versions of fairy tales. Writers should write those stories that they are moved, driven or inspired to write. I mean only to observe that such creations are relatively rare, and to suggest it could be interesting to think about why this might be.

Perhaps it is simply the case that few Australian writers have any particular impulse to create locally set cover versions. Perhaps recognisably Australian settings, particularly of the bush kind, are somewhat out of vogue, and perhaps even a little embarrassing, as Bail seems self-consciously to suggest in Eucalpytus: 
Some description of landscape is necessary. At the same time (be assured) strenuous efforts will be made to avoid the rusty traps set by ideas of a National Landscape, which is of course an interior landscape, fitted out with blue sky and the obligatory tremendous gum tree, perhaps some merinos chewing on the bleached-out grass in the foreground, the kind of landscape seen during home-sickness and in full colour on suburban butchers' calendars ... (1998: 23)

But I suspect that it's something else, and something that goes deeper than the fear of embarrassment one might suffer if caught out unselfconsciously replaying a 'stale version of the national landscape' (Bail 1998: 1).

I suspect that fairy-tale revisionism in Australia is deeply affected by cultural anxieties that stem from this nation's history of colonisation. Australian society, in general, is uncomfortable with anything that forces it to look with unflinching honesty at the facts of its founding. Fairy tales may be set no-specific-where, and no-specific-when, but they hail from deep time, being connected to the present by unbroken chains of repetition. It seems to me that to invoke the formulation 'once upon a time' in a young nation whose history is broken into two utterly unlike components by the cataclysmic events of colonisation/invasion is immediately to raise the question: before or after? Is it the case that when Australian writers (and non-Indigenous Australian writers in particular) consider setting European fairy tales in Australian settings, they are uncomfortably forced to confront deep time? In confronting deep time, do they discover that they must - as Bradford suggests - work out how they are going "to "manage" the colonial past [whether to] obscure the violent origins of the contemporary nation' (Bradford 2001: 15), or illuminate them? Is it possible that it seems safer and easier, to set new works in Europe, or a fantasy world?

Carmel Bird, in the essay that opens Griffith Review's Once upon a time in Oz edition, says that 'Australia is a story as well as a place' (2013: 11). She goes on to say that the 'shocking, defining moment in 1788 when the First Fleet landed fractures the backbone of the story' (2013: 12). This word 'fracture' is important. I wonder if it is the case that not only that the story of Australia is fractured at the moment of invasion/settlement, but also that the European fairy-tale tradition fractures - again and again, and even now - when it comes into contact with Australian landscape and society. Do Australian writers worry that revising traditional European tales in an Australian landscape might perpetuate an early colonial agenda: to 'reassure readers about their status as inheritors of the ancient (European) traditions of fantasy transposed into a new land' (Bradford 2001: 117)? Or have Australian writers silently, and perhaps even subconsciously, made a tacit agreement that revised European fairy tales, of the cover version kind, may not be appropriate in an Australian setting? Do these questions and issues resonate differently for Indigenous Australian writers and non-Indigenous Australian writers? Are writers being tentative, delicate, artful, subversive, or all of the above, when they choose to glue/stitch/insert small pieces of a fractured fairy-tale tradition into new stories, rather than make an attempt at reconstruction?

I have now drifted beyond the scope of this paper - which observes the relative rarity of whole contemporary fairy tales in Australian settings - and into the realm that I hope to navigate next, which is the relationship between contemporary Australian fairy-tale 
revisions and the legacy of colonisation. Bullen and Sawer go some way towards exploring this territory in their analysis of Australian fairy-tale film, in which they argue that 'Australia's colonial history circumscribed the growth of a national fairy-tale tradition' (2016: 235). While their arguments chime with my observations, Bullen and Sawer's research objectives are distinct from mine. Because they focus on identifying an emergent tradition of 'uniquely Australian fairy tales' (2016: 234) - ones that were neither derived from the European tradition, nor appropriations of traditional Australian Aboriginal narratives (which Bullen and Sawer argue should not be considered as fairy tale) - they do not address issues of fairy-tale revisionism at length. Certainly, however, they observe the limited, contested and partial appearance of the fairy tale in Australian creative output.

I do not think that fairy tales are 'everywhere' in Australian literature, not even in a manner of speaking. However, interest in fairy tales is widespread, and growing, in this country. There could usefully be more discussion in Australian fairy-tale scholarship about the issues that Australian writers encounter if/when they consider experimenting with fairy-tale revisionism in an Australian setting. And with an awareness and appreciation of the close relationship between fairy-tale scholars and writers of revisionist fairy tales, both here and abroad, I'd like to end by posing this provocation to us all.

\section{Works cited}

Bail, M 1998 Eucalyptus Melbourne: Text

Bird, C 2004 Cape Grimm Sydney: Harper Collins

Bird, C 2013 'Dreaming the place’ in J Schulz and C Bird (eds) Once upon a time in Oz, Griffith Review 42: 10-21

Bird, C 2015 Fair game Braidwood: Finlay Lloyd

Bird, C 1998 Red shoes Milsons Point: Vintage

Bird, C 1995 The white garden St Lucia: University of Queensland Press

Bradford, C 2001 Reading race: Aboriginality in Australian children's literature Melbourne: Melbourne University Press

Bradley, J 2012 Beauty’s sister Melbourne: Penguin

Bullen, E and N Sawers 2016 ‘Australian fairy-tale films’ Fairy Tale films beyond Disney:

International perspectives J Zipes, P Greenhill and K Magnus-Johnston (eds) New York: Routledge, 233-245

Butler, J 2010 'Musical works, cover versions and strange little girls' Volume 7, 1 at https://volume.revues.org/2826 (accessed 11 August 2016)

Carter, A 1995 [1979] The bloody chamber London: Vintage

Carmody, I and N McNab 2011 Tales from the tower volume one: The wilful eye Crows Nest: Allen \& Unwin

Carmody, I and N McNab 2011 Tales from the tower volume two: The wicked wood Crows Nest: Allen \& Unwin

de Caro, F and R. Jordan 2004, Re-situating folklore: Folk contexts and twentieth-century literature and art Knoxville: University of Tennessee Press 
Do Rozario, R 2011 ‘Australia’s fairy tales illustrated in print: Instances of indigeneity, colonization, and suburbanization’ Marvels and Tales 25, 1: 13-32

Duffel, D 2005 Making music with samples San Francisco: Backbeat Books

Fiander, L 2003 'Writing in a "Fairy story landscape"' Journal of the Association for the Study of Australian Literature 2 at http://openjournals.library.usyd.edu.au/index.php/JASAL/article/view/9668 (accessed 12 February 2016)

Forsyth, K 2012 Bitter greens North Sydney: Vintage

Forsyth, K 2015 The Beast’s garden North Sydney: Vintage

Forsyth, K 2016 ‘On fairy tale inspirations: An interview with Kate Forsyth', at firebirdfeathers.com/2016/02/26/on-fairytale-inspirations-an-interview-with-kate-forsyth (accessed 24 January 2017)

Hatten, R 1985 ‘The place of intertextuality in music studies’ American Journal of Semiotics 3, 4: 6982

Joosen, V 2011 Critical and creative perspectives on fairy tales: An intertextual dialogue between fairy-tale scholarship and postmodern retellings Detroit: Wayne State University

Lanagan, M 2012 Sea Hearts Crows Nest: Allen \& Unwin

Maitland, S 2012 'Grimm tales for young and old by Phillip Pullman - Review’ The Guardian, at https://www.theguardian.com/books/2012/oct/05/grimm-tales-philip-pullman-review (accessed 1 July 2016)

Marillier, J 2013 'By bone-light’ in Prickle moon Greenwood: Ticonderoga Publications

Pullman, P 2012 Grimm tales: For young and old London: Penguin

Schulz, J and C. Bird (eds) 2013 'Once upon a time in Oz’ Griffith Review 42

Spicer, M 2009 ‘Strategic intertextuality in three of John Lennon’s late Beatles’ Songs’, ‘The Beast’s garden’, Penguin Australia, at https://penguin.com.au/books/the-beasts-garden-9780857980410 (accessed 1 July 2016)

Smith, KP 2007 The postmodern fairytale: Folkloric intertexts in contemporary fiction Basingstoke: Palgrave Macmillan

Thomas, J 1986 'Woods and castles, towers and huts: Aspects of setting in the fairy tale' Children's Literature in Education 17, 2: 126-134

Warner, M 2014 'How fairytales grew up' The Guardian, at www.theguardian.com/books/2014/dec/12/how-fairytales-grew-up-frozen (accessed 20 November)

Wood, D 2014 Mothers Grimm Crows Nest: Allen \& Unwin

Wood, D 2006 Rosie Little’s cautionary tales for girls Crows Nest: Allen \& Unwin

Zipes, J 1994 Fairy tale as myth/myth as fairy tale Lexington: University Press of Kentucky 